\title{
PREIMPOUNDMENT WATER QUALITY OF RAYSTOWN BRANCH JUNIATA RIVER AND SIX TRIBUTARY STREAMS, SOUTH-CENTRAL PENNSYLVANIA
}

U.S. GEOLOGICAL SURVEY

Water-Resources Investigations 76-57

Prepared in cooperation with the

U.S. Army Corps of Engineers

Baltimore District

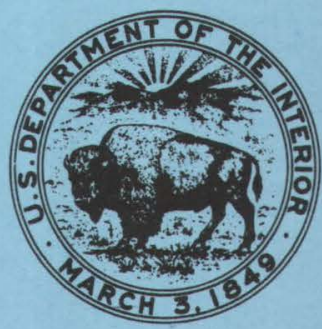




\section{BIBLIOGRAPHI: DATA}

SHEET

4. Title and Subtitle

Preimpoundment Water Quality of Raystown Branch Juniata River and Six Tributary Streams, South-Central Pennsylvania

Donald R. Williams

9. Performing Organization Name and Address

U.S. Geological Survey, Water Resources Division 1000 Liberty Avenue

Pittsburgh, $\mathrm{Pa}$. 15222

12. Sponsoring Organization Name and Address

U.S. Geological Survey, Water Resources Division 1000 Liberty Avenue

Pittsburgh, Pa. 15222

3. Recipient's Accession No.

5. Report Date

June 1976

6.

8. Performing Organization Rept. No. USGS/WRI 76-57

10. Project/Task/Work Unit No.

11. Contract/Grant No.

13. Type of Report \& Period Covered Interim July 1972 - March 1975

14.

15. Supplementary Notes

Prepared in cooperation with the U.S. Army Corps of Engineers, Baltimore District.

16. Abstracts The Raystown Branch Juniata River watershed, which is the main water source for Raystown Lake, is a 960-square-mile (2,490 square kilometres) drainage basin in south-central Pennsylvania. Preimpoundment water-quality data were collected on the Raystown Branch and six tributary streams in the basin. Specific conductance values varied inversely with water discharge. The $\mathrm{pH}$ values were extremely low only at the Shoup Run site. Dissolved oxygen concentrations observed at all sites indicated a relatively high oxygen saturation level throughout the year. Seasonal variations in nitrate$N$ and orthophosphate-P levels were measured at the main inflow station at Saxton, Pa. The highest concentrations of nitrate-N and orthophosphate-P occurred in the winter and spring months and the lowest concentrations were measured during the summer and fall. Bacteriological data indicated no excessive awounts of fecal matter present at the inflows. Soil samples collected at four sites in the impoundment area were predominantly of the Barbour, Philo, and Basher series, which are considered to be highly fertile soils with silt-loam and sandy-loam textures. Morphological features of the lake basin and low putrient levels at the inflows should prevent excessive weed growth around the lake berimeter

17. Key Words and Document Analysis. 17a. Descriptors

*Nutrients, *preimpoundment, *limnology, *water quality, watersheds, chemical properties, physical properties, alkalinity, conductivity, water temperature, bacteria, coliforms, streptococcus, Pennsylvania

17b. Identifiers, Opentenied lerms

*Limnology survsv, Raystown Srau i, Juniata River Basin

17c. $\cos A T !$ ! w : Circutis

18. Avalability ratemen:

No restriction on distribution
19. Security Class (This Report) UNCILASSIFIED

20. Security Class (This Page
21. No. of Pages 28

22. Price 
PREIMPOUNDMENT WATER QUALITY OF

RAYSTOWN BRANCH JUNIATA RIVER AND

SIX TRIBUTARY STREAMS, SOUTH-CENTRAL PENNSYLVANIA

By Donald R. Williams

U.S. GEOLOGICAL SURVEY

Water Resources Investigations 76-57

Prepared in cooperation with the

U.S. Army Corps of Engineers

Baltimore District

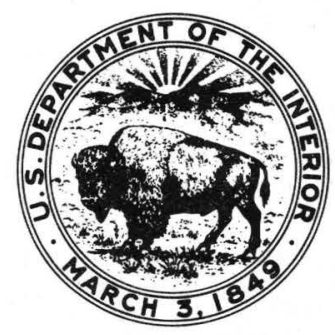

June 1976 


\section{UNITED STATES DEPARTMENT OF THE INTERIOR}

Thomas S. Kleppe, Secretary

\section{GEOLOGICAL SURVEY}

V. E. McKelvey, Director

For additional information write to:

U.S. Geological Survey

Room 2204, Federal Building

1000 Liberty Avenue

Pittsburgh, Pennsylvania 15222 


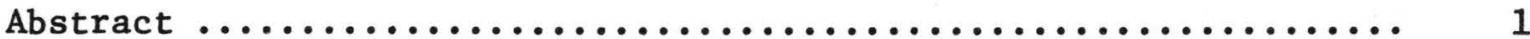

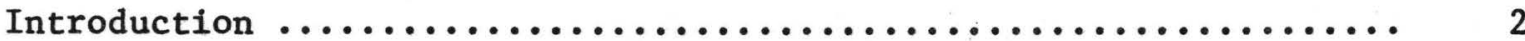

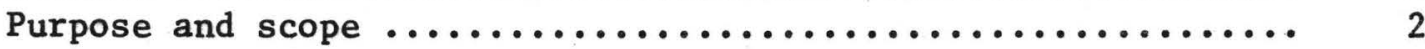

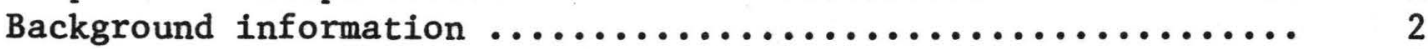

Water Quality ..................................... 4

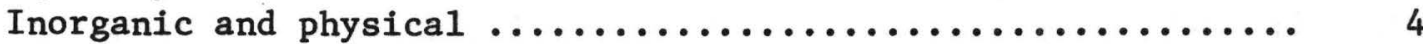

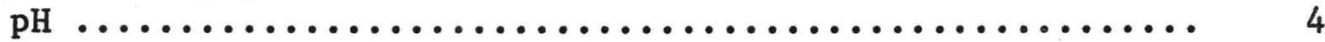

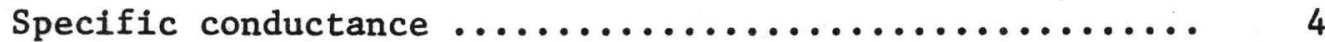

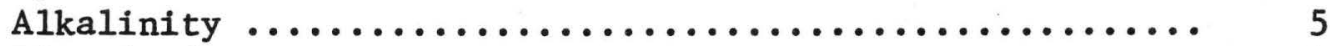

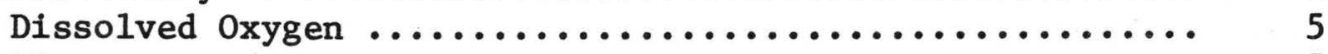

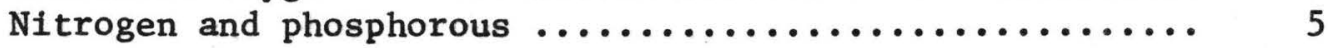

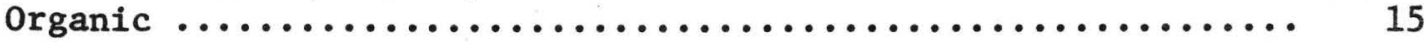

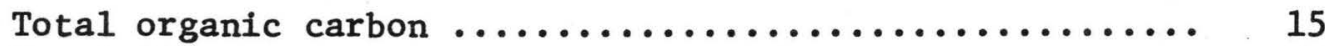

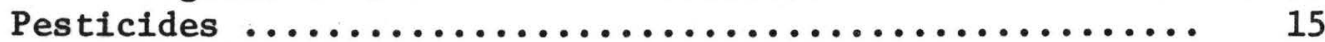

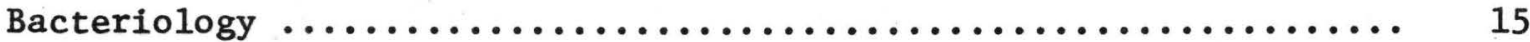

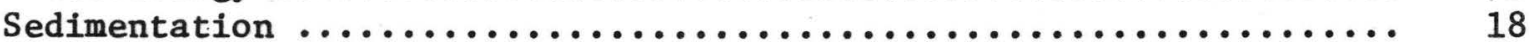

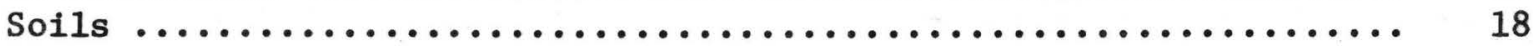

Prognosis of physical, chemical, and biological

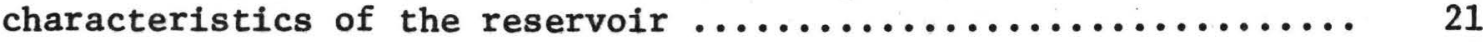

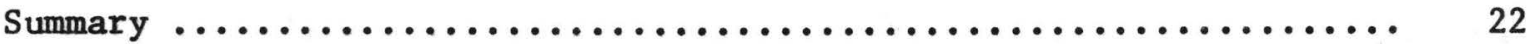

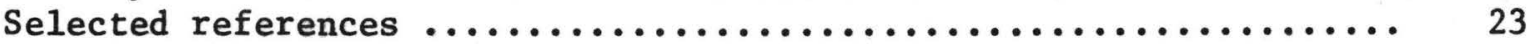

\section{ILLUSTRATIONS}

Figure 1. Map showing Raystown Branch Juniata River drainage basin ..........................

2. Map showing sampling sites in the Raystown

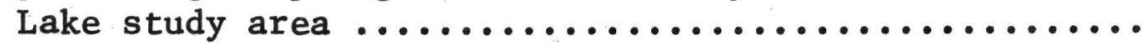

3. Graph showing relationship between discharge and specific conductance at Raystown Branch Juniata River at Saxton (1-5620.) ................

4. Graph showing seasonal variations between specific conductance and total alkalinity and between nitrate-N and orthophosphate-P concentrations at Raystown Branch Juniata

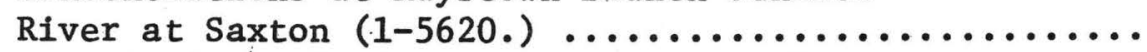

5. Graph showing relationship between total alkalinity and specific conductance at Raystown Branch Juniata River at

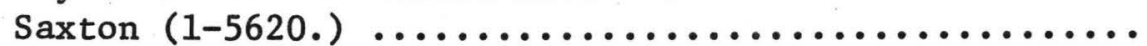




\section{TABLES}

Page

Table 1. The twelve water-quality sampling sites in the Raystown Branch study area ................... 6

2. Physical, chemical, and bacteriological analyses of streams ........................ 8

3. Pesticide analyses - Raystown Branch Juniata River near Hesston, Pa. (1-5627.) ................ 16

4. Particle-size analyses of bed material samples ................................... 19

5. Nitrogen and phosphorous analyses of soil samples ................................. 20

FACTORS FOR CONVERTING ENGLISH UNITS TO INTERNATIONAL SYSTEM (SI) UNITS

English

Feet ( $f t$ )

Miles (mi)

Acres

Square Miles $\left(\mathrm{mi}^{2}\right)$

Acre-feet (acre-ft)

Cubic feet per second $\left(\mathrm{ft}^{3 / \mathrm{s}}\right)$
Multiply by

.3048

1.609

.4047

2.590

.001233

.02832
Metric

Metres (m) Kilometres (km)

Hectares (ha)

Square Kilometres ( $\left.\mathrm{km}^{2}\right)$ Cubic hectometres ( $\left.\mathrm{hm}^{3}\right)$ Cubic metres per second (m3/s) 


\author{
PREIMPOUNDMENT WATER QUALITY OF \\ RAYSTOWN BRANCH JUNIATA RIVER AND SIX \\ TRIBUTARY STREAMS, SOUTH-CENTRAL PENNSYLVANIA
}

By Donald R. Williams

\begin{abstract}
The Raystown Branch Juniata River watershed, which is the main water source for Raystown Lake, is a 960-square-mile (2,490 square kilometres) drainage basin in south-central Pennsylvania. Preimpoundment water-quality data were collected on the Raystown Branch and six tributary streams in the basin. Specific conductance values varied inversely with water discharge. The $\mathrm{pH}$ values were extremely low only at the Shoup Run site. Dissolved oxygen concentrations observed at all sites indicated a relatively high oxygen saturation level throughout the year. Seasonal variations in nitrate-N and or thophosphate-P levels were measured at the main inflow station at Saxton, $\mathrm{Pa}$. The highest concentrations of nitrate-N and orthophosphate-P occurred in the winter and spring months and the lowest concentrations were measured during the summer and fall. Bacteriological data indicated no excessive amounts of fecal matter present at the inflows.

Soil samples collected at four sites in the impoundment area were predominantly of the Barbour, Philo, and Basher series, which are considered to be highly fertile soils with silt-loam and sandy-loam textures. Morphological features of the lake basin and low nutrient levels at the inflows should prevent excessive weed growth around the lake perimeter.
\end{abstract}




\section{INTRODUCTION}

\section{Purpose and Scope}

This interim report presents the preimpoundment water-quality of the Raystown Branch Juniata River and six tributary streams that have perennial flow into the impoundment area. Information collected on water quality, bacteria, sediment, and soils are used to describe the preimpoundment environmental condition and to predict the physical, chemical, and biological characteristics of the reservoir.

\section{Background Information}

The Raystown Branch Juniata River drainage basin is shown in figure 1. The $960 \mathrm{mi}^{2}\left(2,490 \mathrm{~km}^{2}\right)$ basin lies in south-central Pennsylvania in Huntingdon, Bedford, and Fulton Counties. The nearest large city is Altoona, Pa. The watershed is approximately $57 \mathrm{mi}(92 \mathrm{~km})$ 1ong with a maximum width of about 35 $\mathrm{mi}(56 \mathrm{~km})$. It is bounded by the drainage divide of the Frankstown Branch to the north, the Allegheny Front to the west, the Potomac River divide to the south, and the Augwick Creek divide to the east.

The Raystown Branch rises on the west side of the Allegheny Front near Roxbury, $\mathrm{Pa}$, and flows in an easterly direction for about $48 \mathrm{mi}$ (77 km), then northerly in a generally sinuous course for about $76 \mathrm{mi}(122 \mathrm{~km})$ to its confluence with the Juniata River.

The Raystown Branch watershed is in the Ridge and Valley section of the Appalachian Highlands physiographic province and is underlain principally by shale and sandstone. The watershed is mostly wooded with only a small part in cultivation.

Construction of the dam was completed by the U.S. Army Corps of Engineers, Baltimore District, in November 1973. The dam is on the Raystown Branch, $5.5 \mathrm{mi}$ $(8.8 \mathrm{~km})$ upstream from its confluence with the Juniata River. Raystown Lake was designed to provide flood control, recreation, and water-quality control of the outflowing water and to enhance the fishery resource. The recreation pool at elevation $786 \mathrm{ft}(240 \mathrm{~m})$ above mean sea level will have an area of 8,300 acres $(3,360 \mathrm{ha})$ and will extend $30 \mathrm{mi}(48 \mathrm{~km})$ upstream. The flood control pool at elevation $812 \mathrm{ft}(247 \mathrm{~m})$ above mean sea leve1, with a surface area of 10,800 acres $(4,370 \mathrm{ha})$ will extend $34 \mathrm{mi}(55 \mathrm{~km})$ upstream.

The Raystown Branch Juniata River at Saxton, Pa., (1-5620) has a drainage area of $756 \mathrm{mi}^{2}\left(1,958 \mathrm{~km}^{2}\right)$ which is 79 percent of the drainage area controlled by the dam. The quality of water at this site is essentially the quality of water that is filling the lake. The six tributary sites have a combined drainage area of $155 \mathrm{mi}^{2}\left(401 \mathrm{~km}^{2}\right)$, which is only 16 percent of the controlled drainage area. 


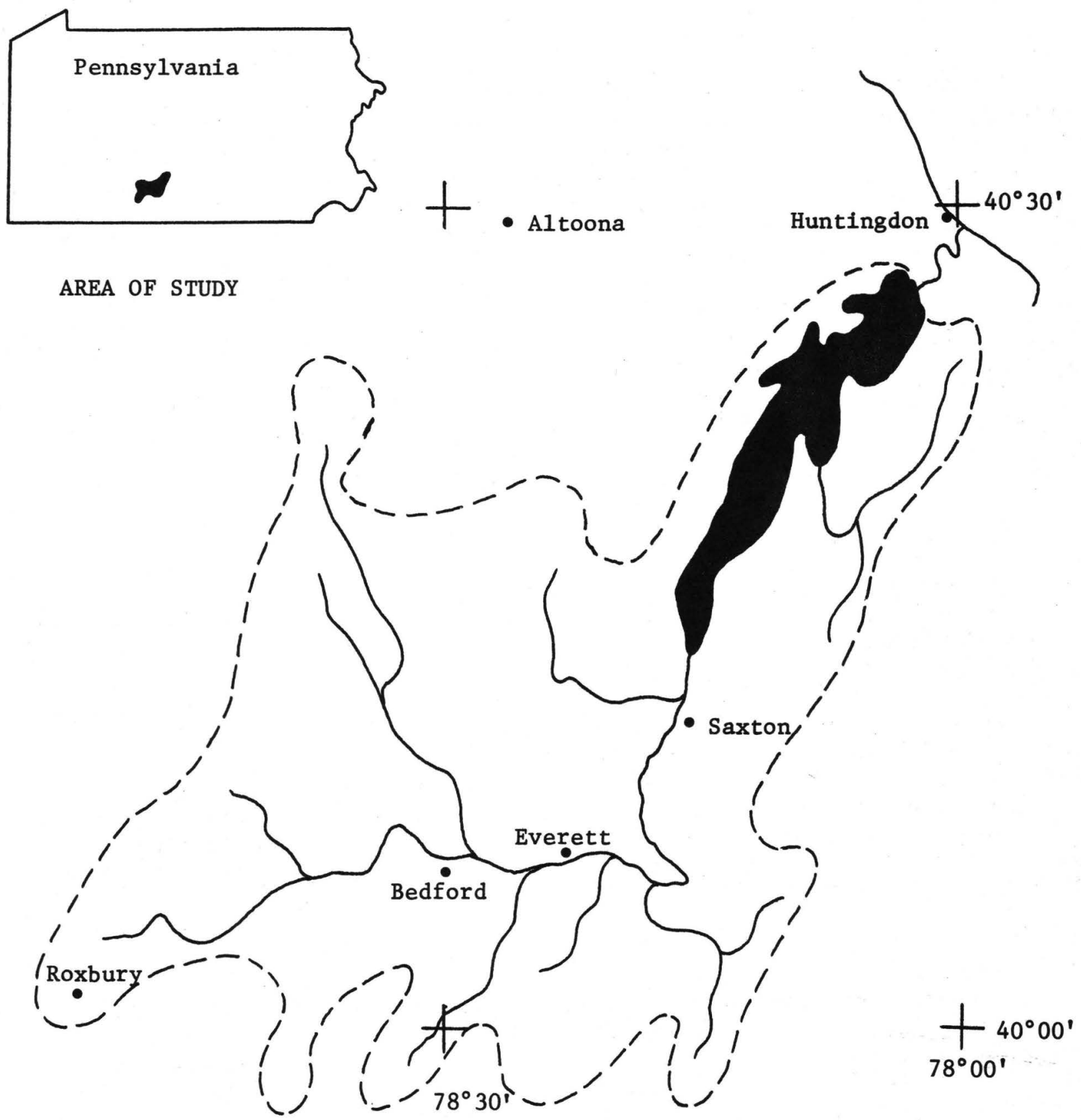

EXPLANATION

- D Drainage divide

Deservoir site

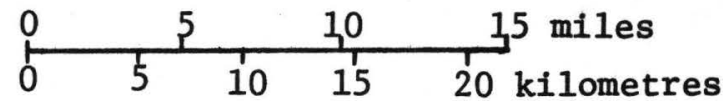

Figure 1.--Raystown Branch Juniata River drainage basin. 
In July 1972, water-quality data collection was begun at 12 sampling sites. The name, station number, and drainage area for each water-quality site is listed in table 1. The locations of all sampling sites are shown in figure 2 . Six water-quality sites were located on the main stem, four of which will become the primary impoundment sites when inundated. The other two main-stem sites were at the inflow and outflow. The six remaining sites were the principle tributary streams to the impoundment. Preimpoundment data collection at the four impoundment sites and the James Creek site was discontinued in May 1973 because of inaccessibility caused by backwater created by partial filling of the lake. Preimpoundment water-quality data collected at all 12 sites are listed in table 2 .

\section{WATER QUALITY}

Inorganic and Physical

$\mathrm{pH}$

Values for $\mathrm{pH}$ at the Saxton site (1-5620.) ranged from 6.2 to 8.4 with a median value of 7.1. This $\mathrm{pH}$ range was generally the same at all of the other sites with the exception of Shoup Run (1-5620.1), Great Trough Creek (1-5625.), and Coffee Run (1-5623.5). Shoup Run had a pH range of 3.2 to 4.4 with a median value of 3.7. This is an acid-bearing stream draining a coal mining area east of Saxton. The comparatively small amount of acid from Shoup Run does not adversely effect the main stem water quality, because of the relatively high buffering capacity of the main stem and the factor of dilution. Great Trough Creek was slightly acidic with a $\mathrm{pH}$ range of 5.4 to 7.3 . The upper reaches of this stream drain the same coal fields as Shoup Run, but the acid effect is much less, as demonstrated by the $\mathrm{pH}$ values. Coffee Run contained waters that were alkaline, having a median $\mathrm{pH}$ of 8.1 .

\section{Specific Conductance}

An inverse relationship existed between stream discharge and specific conductance at the main inflow station at Saxton. Specific conductance was low during the winter and spring months, when surface water runoff increased the water discharge. Specific conductance was high throughout the summer and fall, when ground water had major effect on streamflow and water discharge decreased, indicating a higher concentration of dissolved solids during summer and fall. This indirect relationship between discharge and specific conductance is depicted in Figure 3.

Seasonal variations in specific conductance values at Saxton are illustrated in Figure 4. Specific conductance values at the other five main-stem sites paralleled those at Saxton, indicating no appreciable amount of dissolved solids entering the impoundment area through ground water or from surface water runoff. 
At the Saxton site a direct relationship existed between specific conductance and total alkalinity. As the alkalinity of the water increased, the specific conductance increased proportionately. Likewise, with a decrease in alkalinity, specific conductance decreased. This relationship is illustrated in figure 5 .

On1y 1 out of 17 samples collected at Saxton had a $\mathrm{pH}$ exceeding 8.3, indicating little or no carbonate ion concentration in the water. Therefore, the alkalinity was caused primarily by the bicarbonate ion concentration. A seasonal variation in alkalinity, similar to the seasonal variation in specific conductance was observed at Saxton and is illustrated in figure 4.

\section{Dissolved Oxygen}

The dissolved oxygen concentration of samples collected at the six mainstem sites ranged from 7.2 to $14.0 \mathrm{mg} / 1$ (milligrams per litre). The percentage saturation range was from 85 to 121 . At the six tributary sites, measured dissolved oxygen concentrations were from 7.0 to $13.8 \mathrm{mg} / 1$ with a saturation range from 79 to 106. These data indicate adequate dissolved oxygen concentrations for sustaining diverse aquatic communities, or at least a good oxygen recovery from any polluted reach upstream from the sampling sites.

\section{Nitrogen and Phosphorous}

Three forms of nitrogen, nitrate nitrogen $\left(\mathrm{NO}_{3}-\mathrm{N}\right)$, ammonia nitrogen $\left(\mathrm{NH}_{4}-\mathrm{N}\right)$, and organic nitrogen were analyzed at the Saxton site. The concentration range and median value for each form were as follows:

$$
\text { range (mg/1) }
$$

nitrate-N
ammonia-N
organic nitrogen

$$
\begin{gathered}
0.10-1.5 \\
.02-.38 \\
.06-.92
\end{gathered}
$$

median value (mg/1)

$$
\begin{aligned}
& 1.1 \\
& .07 \\
& .45
\end{aligned}
$$

There is some indication of seasonal variation in nitrate- $\mathrm{N}$ concentrations, with higher concentrations in the winter and lower concentrations in the summer. The increase in the winter can be attributed to increased runoff, and lower concentrations in the summer can be due to nitrate- $\mathrm{N}$ assimilation by aquatic plants, phytoplankton, and bacteria. Ammonia-N concentrations were generally less than $0.10 \mathrm{mg} / 1$, and organic nitrogen concentrations were all less than $0.92 \mathrm{mg} / 1$. Low concentrations of these two nitrogen compounds indicate the stream to be mostly free of organic pollution.

Only on one occasion did the total phosphorous concentration exceed 0.10 $\mathrm{mg} / 1$. The range was from 0.01 to $0.17 \mathrm{mg} / 1$, and the median was $0.03 \mathrm{mg} / 1$. The orthophosphate-P concentration range was from 0.0 to $0.08 \mathrm{mg} / 1$, and the median was $0.02 \mathrm{mg} / 1$. As with nitrate- $\mathrm{N}$, the highest orthophospate-P concentrations at the Saxton site occurred during the winter and the lowest concentrations during the summer. This seasonal variation in nitrate-N and orthophosphate-P concentrations is depicted in figure 4. 
Table 1.--The twelve water quality sampling sites in the Raystown Branch study area.

Station Number

$1-5620$.

$1-5623$.

1-5624.

$1-5627$.

1-5630.

$1-5632.1$

$1-5620.1$

1-5622.

$1-5622.5$

$1-5623.5$

1-5625.

$1-5626$.
Drainage area $\left(\mathrm{m}^{2}\right)$

756

-

957

963

21.8

12.0

7.9

7.2

85.4

20.5
Station Name

Raystown Branch Juniata River at Saxton, $\mathrm{Pa}$.

Raystown Branch

Juniata River near Entriken, $\mathrm{Pa}$.

Raystown Branch Juniata River near Marklesburg, $\mathrm{Pa}$.

Raystown Branch Juniata River near Hesston, $\mathrm{Pa}$.

Raystown Branch Juniata River near Huntingdon, $\mathrm{Pa}$.

Raystown Branch Juniata River at Ardenheim, $\mathrm{Pa}$.

Shoup Run at Saxton, $\mathrm{Pa}$.

Shy Beaver Creek near Entriken, $\mathrm{Pa}$.

Tatman Run near Entriken, $\mathrm{Pa}$.

Coffee Run near Entriken, $\mathrm{Pa}$.

Great Trough Creek near Marklesburg, $\mathrm{Pa}$.

James Creek near Marklesburg, $\mathrm{Pa}$. 


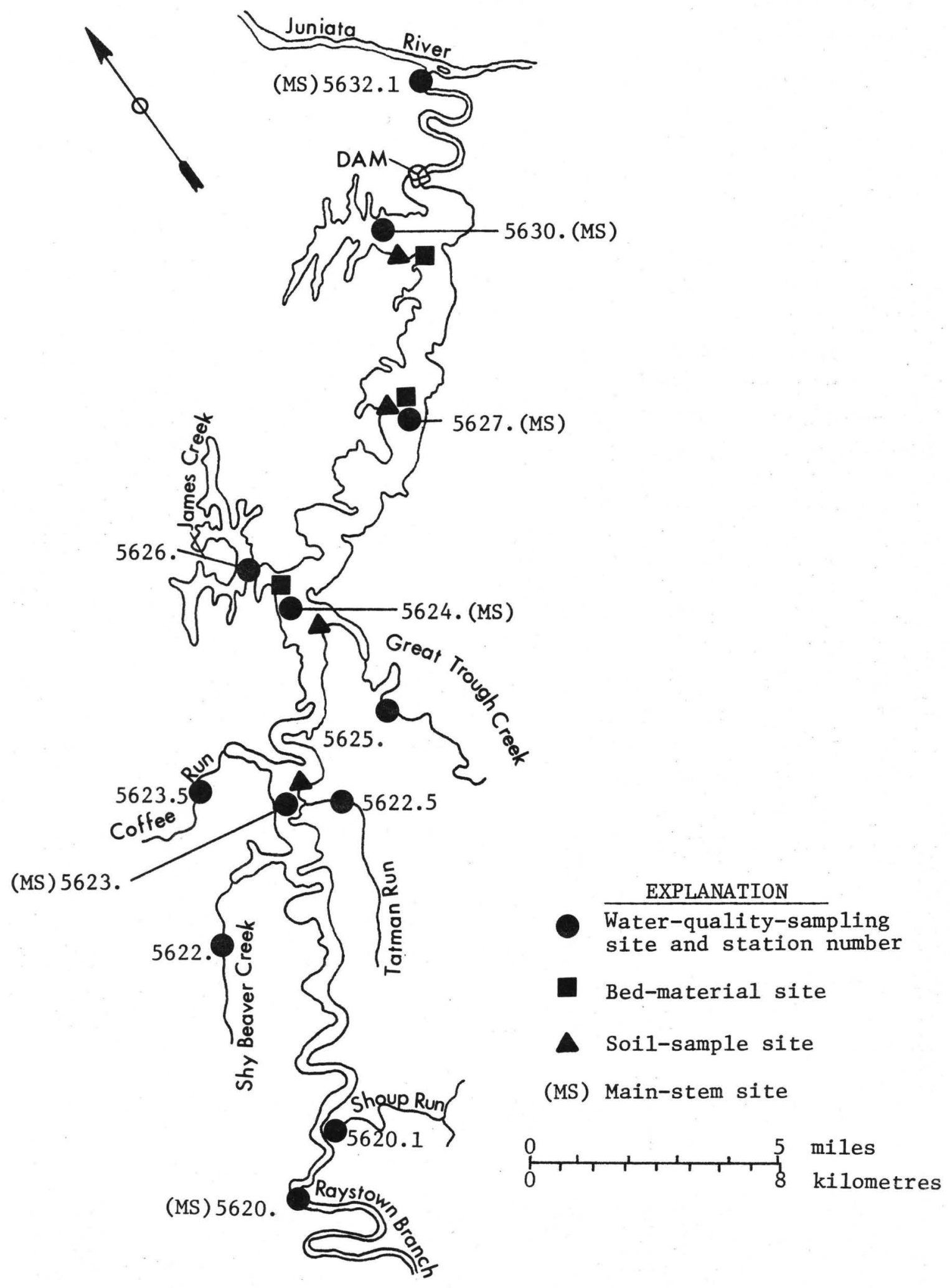

Figure 2.--Sampling sites in the Raystown Lake study area. 
Table 2.--Physical, chemical, and bacteriological analyses of streams.

(Chemical analyses in milligrams per litre, except as noted)

\begin{tabular}{|c|c|c|c|c|c|c|c|c|c|c|c|c|c|c|c|c|c|}
\hline Date & 真 & 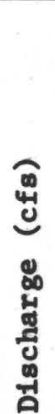 & 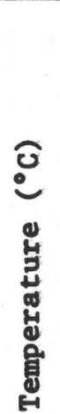 & 园 & 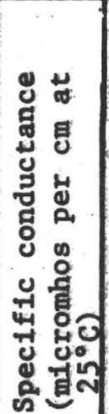 & 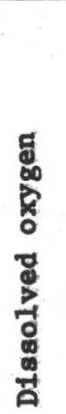 & 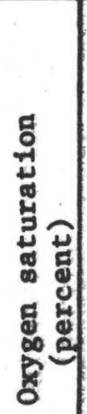 & 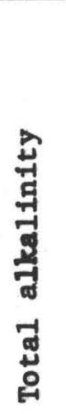 & 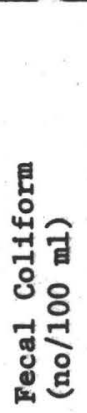 & 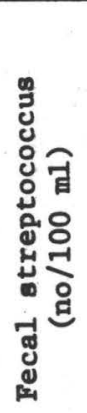 & 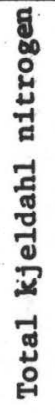 & 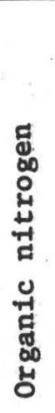 & 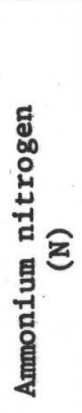 & 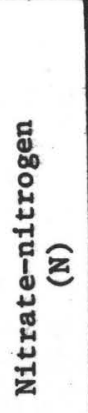 & 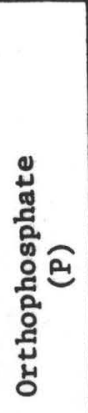 & 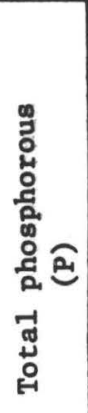 & 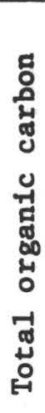 \\
\hline
\end{tabular}

1-5620. Raystown Branch Juniata River at Saxton, Pa.

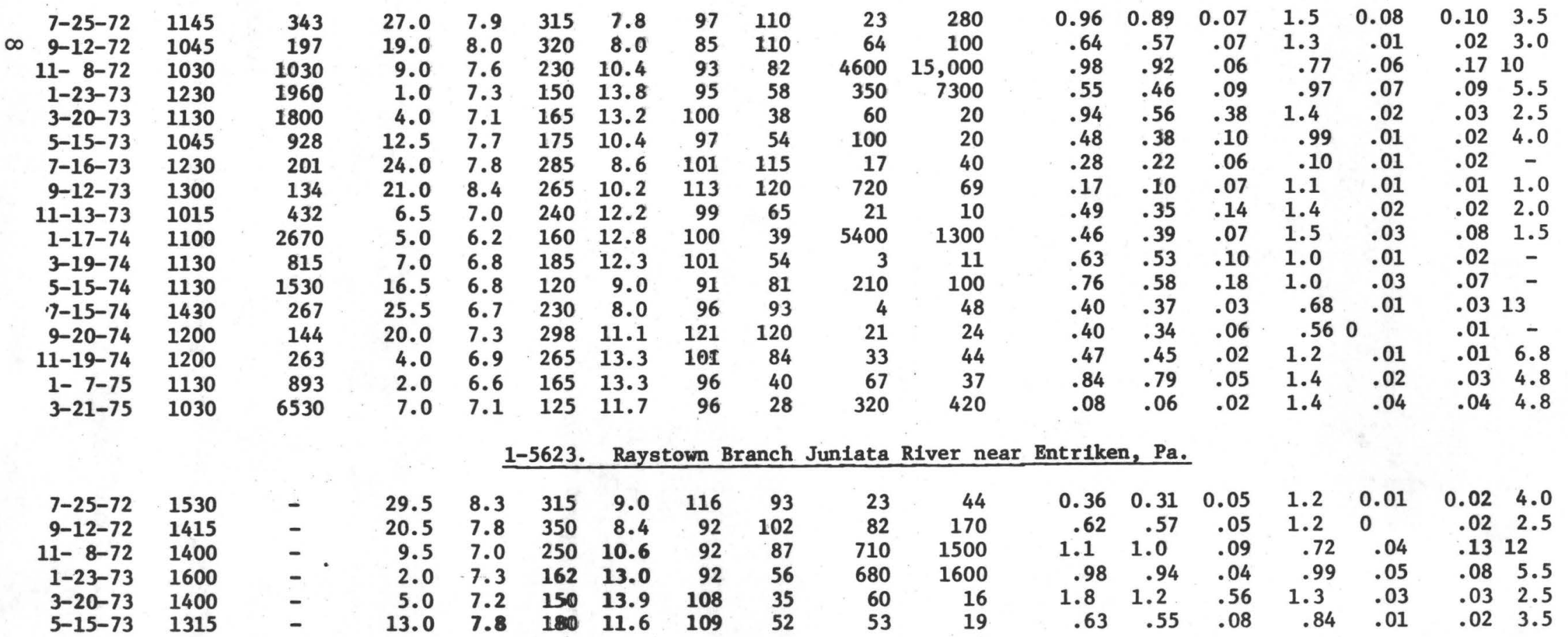


1-5624. Rastown Branch Juniata River near Marklesburg, Pa.

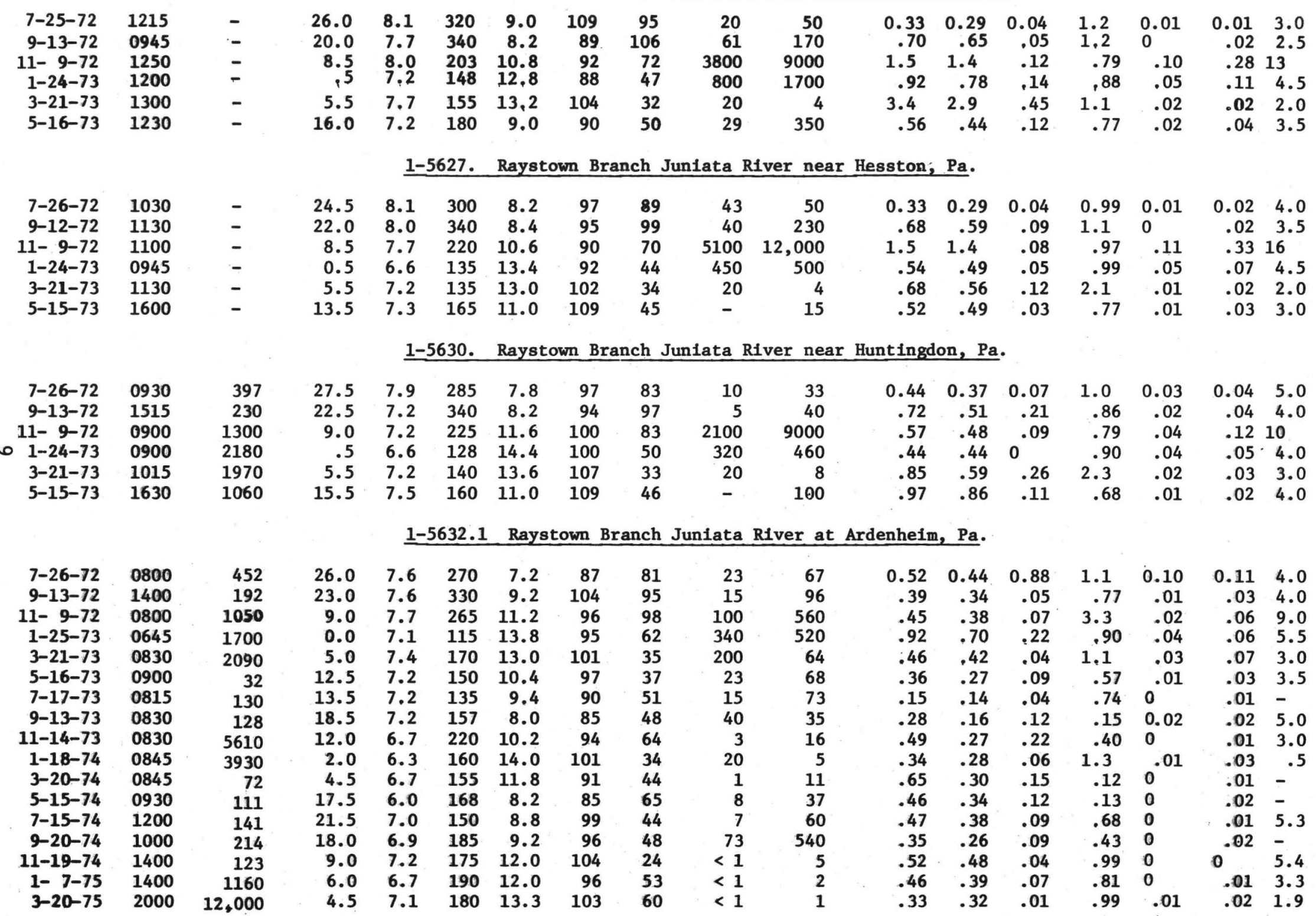


Table 2.--Physical, chemical, and bacteriological analyses of streams--Continued.

\begin{tabular}{|c|c|c|c|c|c|c|c|c|c|c|c|c|c|c|c|c|c|}
\hline Date & 悬 & 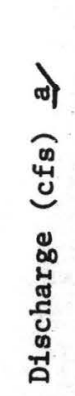 & 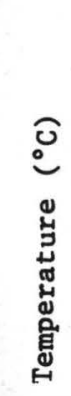 & 思 & 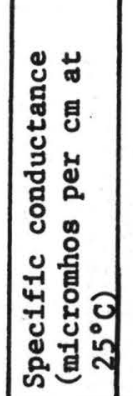 & 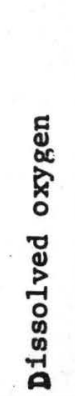 & 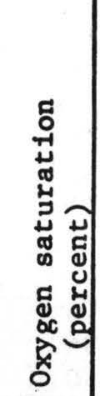 & 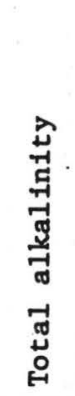 & 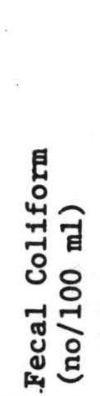 & 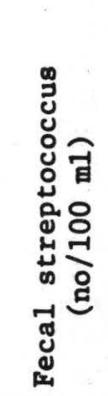 & 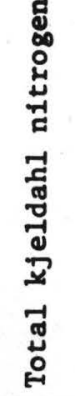 & 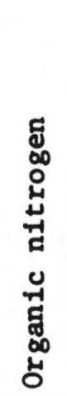 & 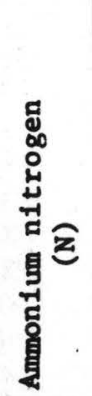 & 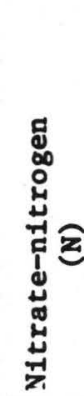 & 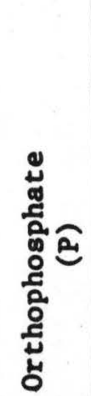 & 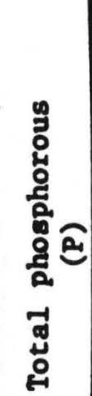 & 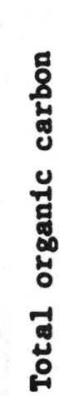 \\
\hline
\end{tabular}

1-5620.1 Shoup Run at Saxton, Pa.

\begin{tabular}{|c|c|c|c|c|c|c|c|c|c|c|c|c|c|c|c|c|c|}
\hline $7-25-72$ & 1310 & 10 & 19.0 & 3.2 & 800 & 8.6 & 91 & - & 0 & 100 & 0.27 & 0.17 & 0.10 & 0.56 & 0.04 & 0.08 & 12 \\
\hline $9-12-72$ & 1130 & 22 & 15.0 & 3.3 & 900 & 9.6 & 94 & - & 4 & 140 & .24 & .13 & .11 & .27 & .01 & .01 & 3.0 \\
\hline $11-8 \div 72$ & 1120 & 52 & 9.0 & 4.4 & 215 & 11.0 & 80 & - & 3600 & 1600 & .78 & .70 & .08 & 2.5 & .03 & .12 & 11 \\
\hline $1-23-73$ & 1315 & 38 & 4.0 & 3.8 & 240 & 13.6 & 102 & - & 7 & 80 & .41 & .29 & .12 & .25 & .01 & .02 & 3.0 \\
\hline $3-20-73$ & 1145 & 36 & 7.5 & 3.6 & 260 & 12.1 & 100 & - & 0 & 32 & .33 & .21 & .12 & .23 & 0 & .05 & 1.5 \\
\hline $5-15-73$ & 1100 & 21 & 10.5 & 3.7 & 300 & 10.0 & 89 & - & 10 & 12 & .13 & .09 & .04 & .18 & 0 & .02 & 2.0 \\
\hline $7-16-73$ & 1300 & 8.0 & 18.0 & 3.9 & 430 & 9.0 & 94 & - & 1 & 10 & .10 & .03 & .07 & .14 & .01 & .02 & - \\
\hline $9-12-73$ & 1330 & 8.0 & 17.0 & 3.3 & 460 & 9.6 & 98 & - & 0 & 6 & .06 & 0 & .06 & .09 & .01 & .02 & 0 \\
\hline $11-13-73$ & 1100 & 37 & 9.0 & 3.4 & 450 & 11.2 & 97 & - & 2 & 36 & .14 & .09 & .05 & .10 & 0 & 0 & 3.5 \\
\hline $1-17-74$ & 1130 & 45 & 6.0 & 4.1 & 190 & 12.5 & 100 & - & 34 & 150 & .26 & .19 & .07 & .43 & 0 & .04 & .5 \\
\hline $3-19-74$ & 1200 & 37 & 8.5 & 3.9 & 270 & 11.6 & 99 & - & 0 & 10 & .18 & .10 & .08 & .20 & .01 & .01 & \\
\hline
\end{tabular}

1-5622. Shy Beaver Creek near Entriken, Pa.

\begin{tabular}{|c|c|c|c|c|c|c|c|c|c|c|c|c|c|c|c|c|c|}
\hline $7-25-72$ & 1645 & 1.1 & 24.0 & 8.1 & 300 & 8.2 & 96 & 122 & 270 & 740 & 0.26 & 0.22 & 0.04 & $\begin{array}{r}0.79 \\
.59\end{array}$ & 0.02 & $\begin{array}{r}0.02 \\
.03\end{array}$ & $\begin{array}{l}4.0 \\
4.0\end{array}$ \\
\hline $\begin{array}{r}9-12-72 \\
11-8-72\end{array}$ & 1640 & 1.2 & 18.0 & 7.7 & 340 & 9.4 & 98 & 139 & 490 & $\begin{array}{r}130 \\
8900\end{array}$ & $\begin{array}{l}.25 \\
.49\end{array}$ & $\begin{array}{l}.18 \\
.43\end{array}$ & .06 & 3.59 & .01 & $\begin{array}{l}.03 \\
.06\end{array}$ & $\begin{array}{l}4.0 \\
9.5\end{array}$ \\
\hline $\begin{array}{r}11-8-72 \\
1-24-73\end{array}$ & 1600 & 31 & $\begin{array}{l}9.0 \\
? .5\end{array}$ & 7.3 & 143 & 10.2 & 88 & $\begin{array}{l}39 \\
55\end{array}$ & $\begin{array}{r}2600 \\
410\end{array}$ & $\begin{array}{l}8900 \\
1200\end{array}$ & $\begin{array}{r}.49 \\
.48\end{array}$ & .38 & .10 & .66 & .02 & .03 & $\begin{array}{l}9.5 \\
4.5\end{array}$ \\
\hline $\begin{array}{l}1-24-73 \\
3-20-73\end{array}$ & $\begin{array}{l}1420 \\
1500\end{array}$ & $\begin{array}{l}12 \\
12\end{array}$ & $\begin{array}{l}2.5 \\
9.0\end{array}$ & $\begin{array}{l}7.3 \\
7.8\end{array}$ & $\begin{array}{l}138 \\
165\end{array}$ & $\begin{array}{l}13.0 \\
12.2\end{array}$ & $\begin{array}{r}95 \\
105\end{array}$ & $\begin{array}{l}30 \\
56\end{array}$ & 10 & 20 & .28 & .19 & .09 & .50 & .01 & .03 & 2.0 \\
\hline $5-15-73$ & 1400 & 8.0 & 13.0 & 7.4 & 180 & 11.2 & 106 & 72 & 260 & 34 & .24 & .17 & .07 & .41 & .01 & .02 & 3.5 \\
\hline $7-16-73$ & 1630 & 3.0 & 22.0 & 8.1 & 280 & 8.7 & 98 & 137 & 190 & 500 & .23 & .18 & .05 & .47 & .02 & .02 & - \\
\hline $9-12-73$ & 1700 & 1.6 & 18.0 & 8.2 & 305 & 9.4 & 98 & 142 & 150 & 570 & .09 & .04 & .05 & .47 & .01 & .02 & 0 \\
\hline $11-13-73$ & 1545 & 6.4 & 9.0 & 7.4 & 310 & 12.0 & 104 & 115 & 29 & 44 & .27 & .19 & .08 & .40 & 0 & .01 & 1.5 \\
\hline $1-17-74$ & 1615 & 50 & 5.0 & 5.0 & 155 & 11.8 & 92 & 31 & 220 & 240 & .45 & .36 & .09 & .77 & .01 & .03 & 2.0 \\
\hline $3-19-74$ & 1630 & 12 & 9.5 & 6.4 & 185 & 11.4 & 99 & 67 & 10 & 18 & .32 & .22 & .10 & .40 & .01 & .02 & - \\
\hline
\end{tabular}

1-5622.5 Tatman Run near Entriken, Pa. 
9-12-72 1220

$1-23-73 \quad 1515$

5-15-73 1300

$7-16-73 \quad 1445$

9-12-73 1530

11-13-73 1320

$1-17-74 \quad 1315$

3-19-74 1315
$11-8-72 \quad 1300$

3-20-73 1345

$\begin{array}{crrrrrr}.30 & 18.0 & 7.5 & 190 & 9.0 & 95 & 63 \\ 8.4 & 8.5 & 7.1 & 110 & 11.0 & 93 & 33 \\ 4.8 & 3.0 & 7.1 & 68 & 12.6 & 93 & 14 \\ 11 & 7.5 & 7.4 & 80 & 11.7 & 97 & 17 \\ 9.6 & 10.0 & 7.1 & 82 & 10.3 & 91 & 21 \\ 1.2 & 22.0 & 7.4 & 155 & 7.0 & 79 & 76 \\ .45 & 18.5 & 7.1 & 200 & 8.6 & 91 & 85 \\ 5.0 & 6.5 & 6.5 & 120 & 10.3 & 84 & 37 \\ 24 & 5.5 & 6.1 & 85 & 12.4 & 98 & 13 \\ 8.0 & 6.0 & 7.1 & 85 & 11.0 & 88 & 24\end{array}$

$\begin{array}{rr}97 & 460 \\ 560 & 4100 \\ 190 & 500 \\ 160 & 320 \\ 290 & 52 \\ 160 & 130 \\ 57 & 32 \\ 260 & 69 \\ 120 & 100 \\ 95 & 47\end{array}$

$\begin{array}{ll}.48 & .40 \\ 1.0 & .77 \\ 1.0 & .76 \\ .36 & .19 \\ .20 & .15 \\ .19 & .13 \\ .04 & 0 \\ .24 & .15 \\ .30 & .21 \\ .27 & .18\end{array}$

$\begin{array}{cc}.93 & .01 \\ 1.6 & .02 \\ .47 & .02 \\ .63 & .04 \\ .23 & .01 \\ .60 & .01 \\ .64 & .01 \\ .40 & .01 \\ .52 & .02 \\ .30 & .01\end{array}$ $\begin{array}{ll}.02 & 4.0 \\ .08 & 10 \\ .02 & 3.0 \\ .08 & 2.5 \\ .04 & 3.0 \\ .02 & - \\ .01 & - \\ .01 & 4.0 \\ .03 & 1.0 \\ .02 & -\end{array}$

1-5623.5 Coffee Run near Entriken, $\mathrm{Pa}$.

$\begin{array}{rrrrrrrrrrrrrrrrrr}2.6 & 25.5 & 8.2 & 330 & 8.0 & 97 & 137 & 320 & 430 & 0.42 & 0.24 & 0.18 & 1.3 & 0.03 & 0.04 & 3.5 \\ 1.5 & 18.0 & 8.0 & 390 & 8.6 & 90 & 158 & 1900 & 3900 & .82 & .77 & .05 & 1.3 & .04 & .04 & 5.0 \\ 8.0 & 8.5 & 6.9 & 218 & 11.0 & 93 & 87 & 12,000 & 7900 & .69 & .64 & .05 & .79 & .04 & .06 & \mathbf{8 . 0} \\ 27 & 2.5 & 7.2 & 120 & 13.4 & 98 & 41 & 150 & 260 & 1.9 & 1.5 & .41 & .50 & .02 & .02 & 3.0 \\ 6.0 & 9.5 & 8.1 & 190 & 11.8 & 102 & 73 & 930 & 140 & .63 & .45 & .18 & .68 & .02 & .04 & 2.5 \\ 5.0 & 12.5 & 8.3 & 185 & 12.0 & 112 & 86 & 930 & 2200 & .06 & .05 & .01 & .57 & .02 & .02 & 3.0 \\ 1.2 & 23.0 & 8.2 & 310 & 8.6 & 99 & 165 & 690 & 500 & .30 & .23 & .07 & 1.1 & .04 & .05 & -04 \\ .60 & 19.0 & 8.2 & 360 & 9.4 & 100 & 171 & 140 & 1400 & .05 & 0 & .05 & .59 & .03 & .04 & 0 \\ 2.5 & 10.0 & 8.3 & 320 & 11.8 & 104 & 133 & 87 & 140 & .39 & .31 & .08 & 1.2 & .02 & .04 & 1.5 \\ 24 & 5.0 & 6.1 & 170 & 12.0 & 94 & 52 & 1500 & 820 & .45 & .36 & .09 & .95 & .02 & .05 & 2.0 \\ 6.0 & 10.5 & 6.5 & 200 & 10.6 & 94 & 80 & 140 & 200 & .46 & .34 & .12 & .80 & .02 & .06 & -02\end{array}$

1-5625. Great Trough Creek near Marklesburg, Pa.

$\begin{array}{rr}7-25-72 & 1245 \\ 9-13-72 & 1100 \\ 11-9-72 & 1320 \\ 1-24-73 & 1230 \\ 3-21-73 & 1330 \\ 5-16-73 & 1200 \\ 7-16-73 & 1500 \\ 9-12-73 & 1600 \\ 11-13-73 & 1300 \\ 1-17-74 & 1330 \\ 3-19-74 & 1400\end{array}$

$\begin{array}{rrrrrrr}29 & 23.5 & 7.2 & 82 & 9.0 & 104 & 20 \\ 5.1 & 19.5 & 6.9 & 120 & 9.4 & 102 & 29 \\ 132 & 7.5 & 6.9 & 100 & 11.4 & 94 & 15 \\ 100 & 1.0 & 6.9 & 60 & 13.2 & 92 & 6 \\ 80 & 5.0 & 7.0 & 65 & 13.2 & 103 & \\ 75 & 10.5 & 6.4 & 70 & 10.8 & 96 & 9 \\ 12 & 23.0 & 6.9 & 72 & 8.8 & 101 & 19 \\ 8.0 & 20.0 & 6.8 & 118 & 9.8 & 107 & 30 \\ 90 & 6.5 & 6.4 & 88 & 12.2 & 99 & 10 \\ 225 & 4.0 & 5.4 & 78 & 12.8 & 97 & 8 \\ 40 & 5.0 & 7.3 & 70 & 12.1 & 94 & 10\end{array}$

$\begin{array}{rrr}20 & 10 & 44 \\ 29 & 420 & 1100 \\ 15 & 1300 & 6900 \\ 6 & 37 & 120 \\ 8 & 20 & 16 \\ 9 & 52 & 16 \\ 19 & 83 & 320 \\ 30 & 34 & 330 \\ 10 & 10 & 16 \\ 8 & 450 & 1000 \\ 10 & 13 & 16\end{array}$

$\begin{array}{ll}0.16 & 0.14 \\ .23 & .17 \\ .51 & .44 \\ 1.8 & 1.6 \\ .19 & .13 \\ .21 & .18 \\ .14 & .08 \\ .08 & .04 \\ .19 & .10 \\ .43 & .33 \\ .26 & .17\end{array}$

0.02
.04
.07
.23
.06
.03
.06
.04
.09
.10
.09

$\begin{array}{cc}0.01 & 4.0 \\ .04 & 4.0 \\ .08 & 10 \\ .04 & 3.0 \\ .01 & 2.5 \\ .03 & 9.5 \\ .02 & - \\ .02 & 1.0 \\ .03 & 3.0 \\ .06 & 2.0 \\ .03 & -\end{array}$

1-5626. James Creek near Marklesburg, Pa.

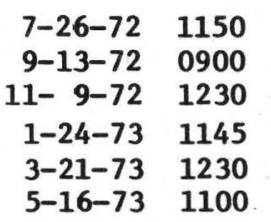

$\begin{array}{rrrrrrrrr}10 & 19.5 & 8.1 & 350 & 9.4 & 101 & 142 & 690 & 770 \\ 3.0 & 18.0 & 7.8 & 360 & 8.0 & 8.3 & 146 & 1700 & 1800 \\ 43 & 8.5 & 7.6 & 170 & 11.0 & 93 & 63 & 1100 & 2000 \\ 40 & 1.5 & 7.3 & 130 & 13.8 & 98 & 56 & 90 & 130 \\ 20 & 6.0 & 7.9 & 190 & 12.6 & 101 & 72 & 13 & 80 \\ 8.0 & 9.0 & 6.8 & 245 & 11.8 & 102 & 97 & 85 & 60\end{array}$

$0.25 \cdot 0.22 \quad 0.03$

$\begin{array}{ll}1.8 & 0.04\end{array}$

0.044 .0

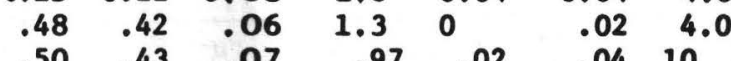
$\begin{array}{lllllll}.50 & .43 & .07 & .97 & .02 & .04 & 10\end{array}$ $\begin{array}{lllllll}.11 & 2.5 & .42 & .54 & .02 & .03 & 2.5\end{array}$ $\begin{array}{lllllll}3.7 & 3.2 & .46 & 1.7 & .01 & .05 & 1.5\end{array}$ $\begin{array}{lllllll}.46 & .41 & .05 & 1.1 & .01 & .03 & 2.5\end{array}$

a. Estimated 
DISCHARGE, IN CUBIC ^METRES PER SECOND

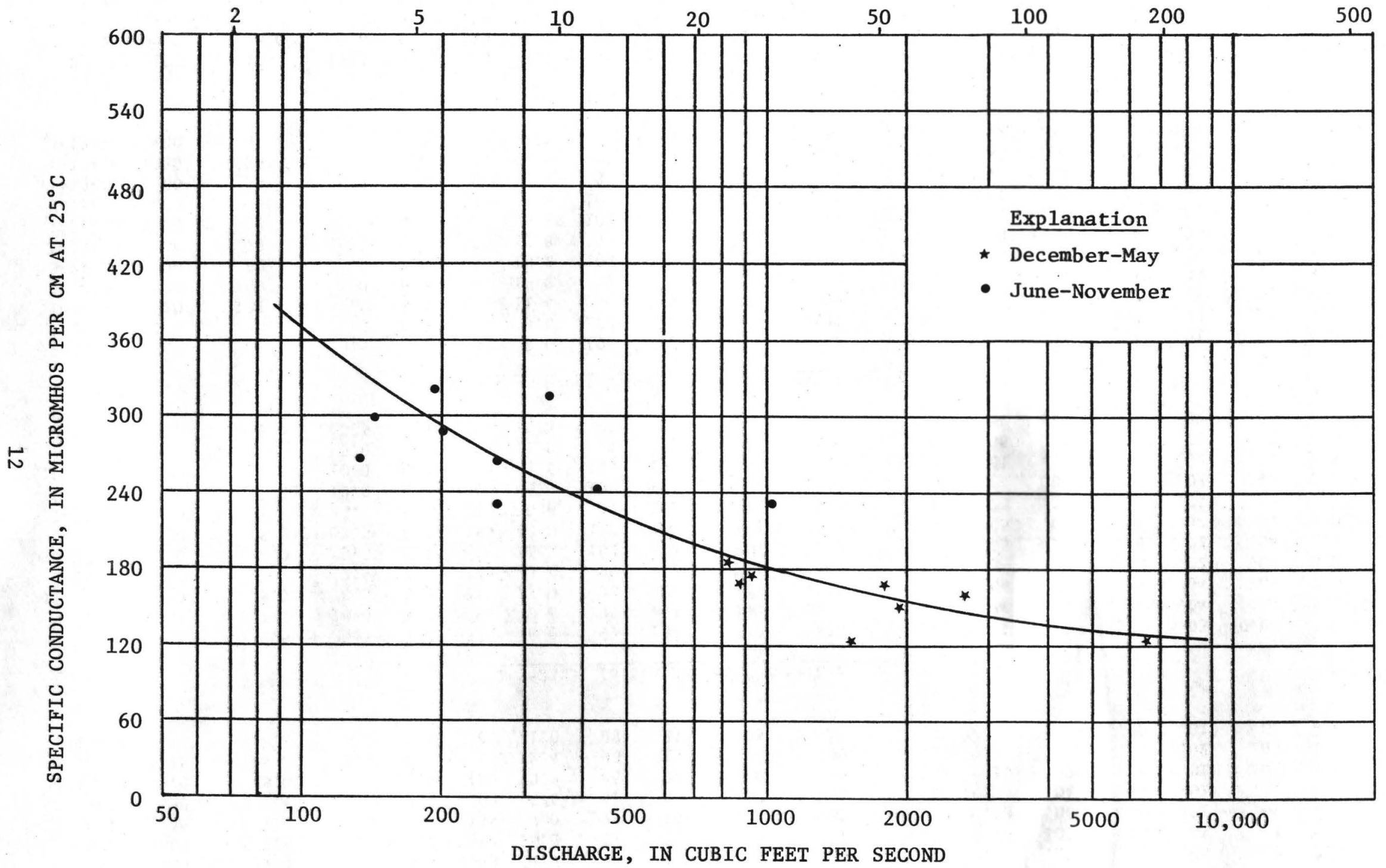

Figure 3.--Relationship between discharge and specific conductance at Raystown Branch Juniata River at Saxton (1-5620.). 


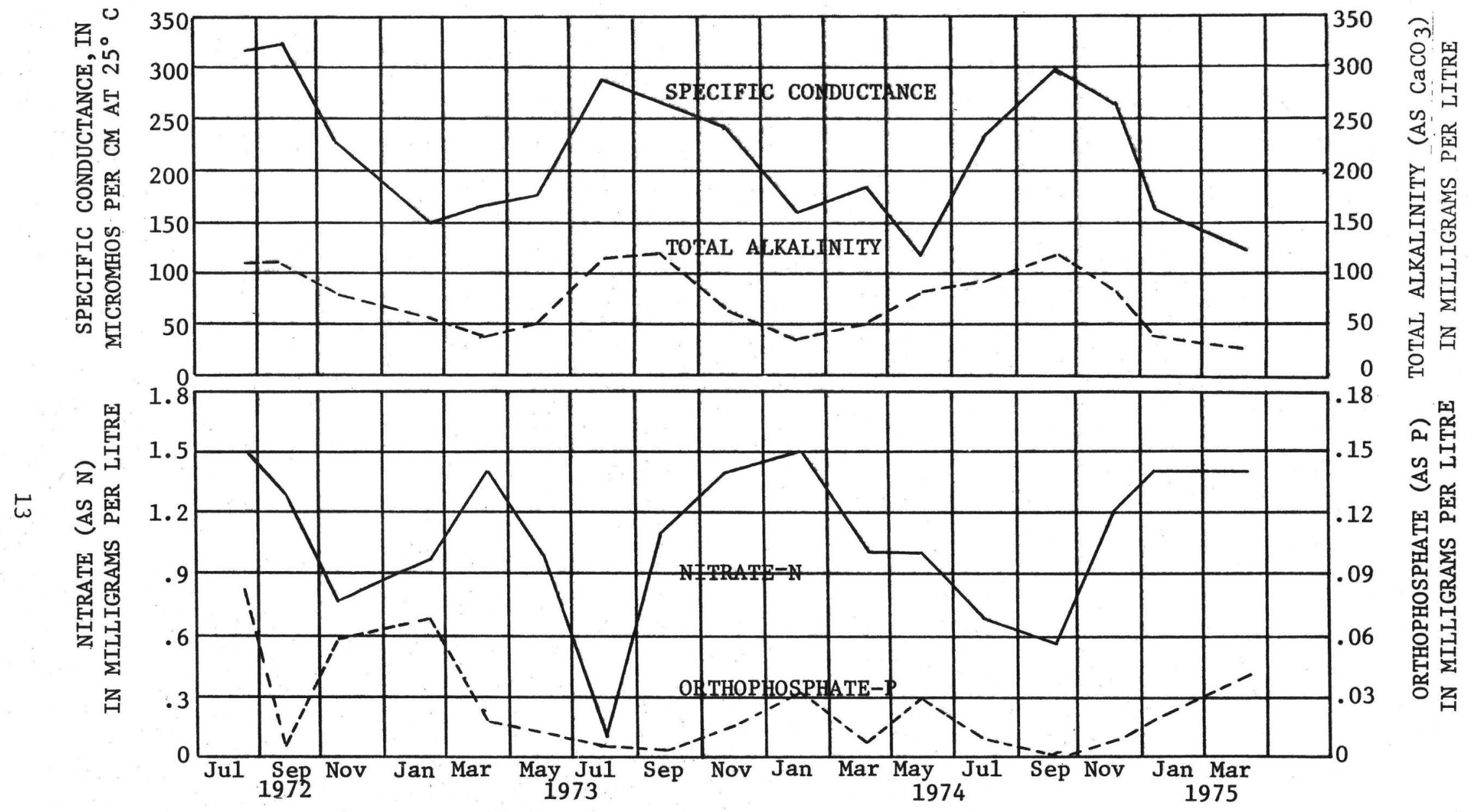

Figure 4.--Seasonal variations between specific conductance and total alkalinity and between nitrate-N and orthophosphate-P concentrations at Raystown Branch Juniata River at Saxton (1-5620.). 


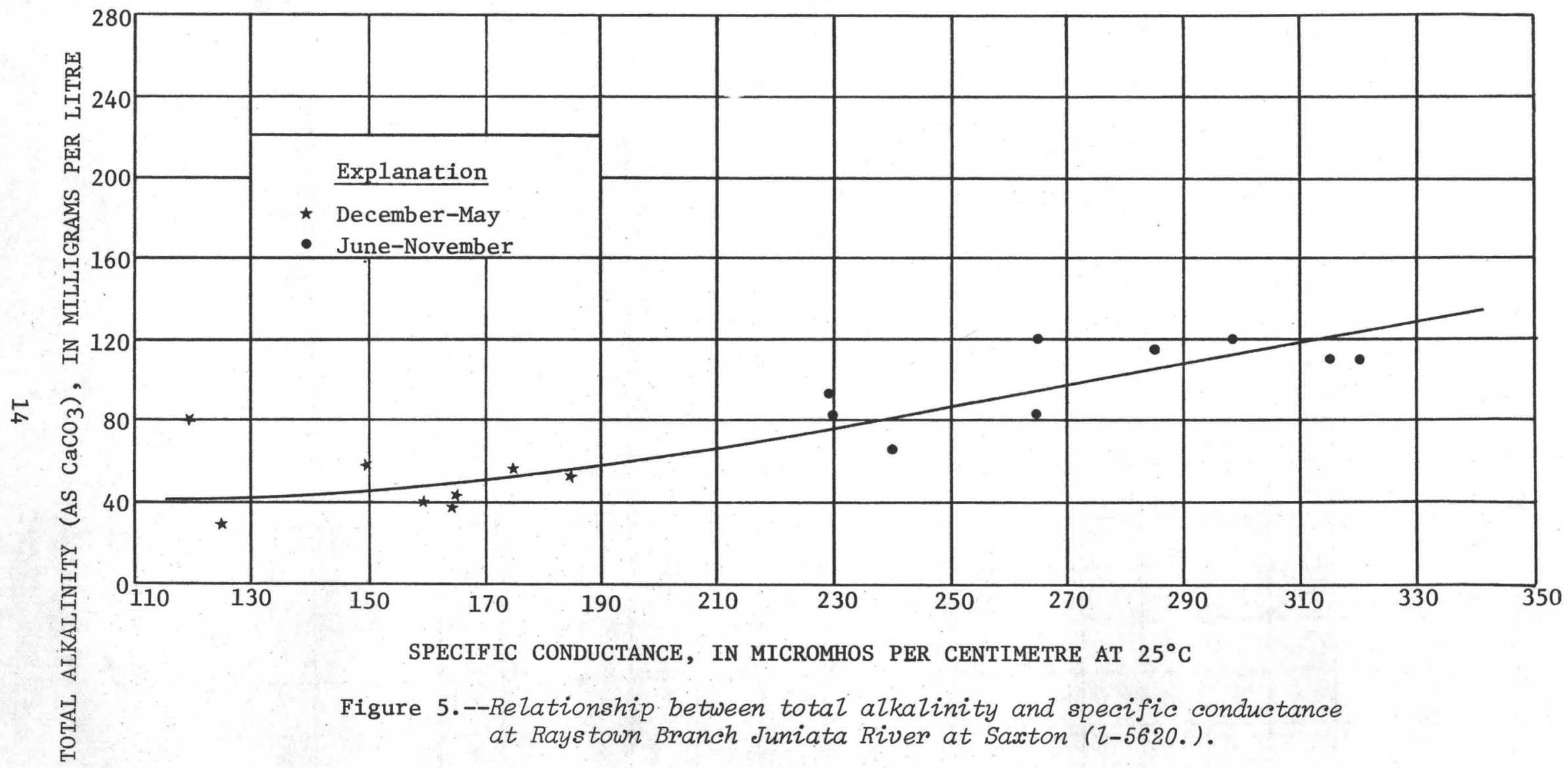




\section{Organic}

Total Organic Carbon

Total organic carbon (TOC) concentrations at the Saxton site ranged from 1.0 to $13.0 \mathrm{mg} / 1$, and the median was $4.0 \mathrm{mg} / 1$. Concentrations less than 6.8 $\mathrm{mg} / 1$ occurred 85 percent of the time. These relatively low TOC concentrations together with the near-saturated dissolved oxygen content indicated no excessive quantities of organic matter present at the main inflow. TOC concentrations at the five other downstream main-stem sites approximated those at Saxton. Similarly, TOC concentrations at the six tributary sites ranged from 0.0 to 12.5 $\mathrm{mg} / 1$, and the median was $3.0 \mathrm{mg} / 1$.

\section{Pesticides}

A suspended sediment sample was collected at a main-stem site (1-5627.) during high water on November 9, 1972, and was analyzed for the common chlorinated hydrocarbon pesticides and organophosphate. Of the 20 compounds analyzed, only trace quantities of 2,4-D and 2,4,5-T were present in the water-sediment mixture. The compound 2,4-D is the best known of present herbicides. It is a plant hormone that stimulates growth, often to the extent of causing a plant to destroy itself. It is non-poisonous but may give water an unpleasant taste. The concentration of 2,4-D found in the water-sediment sample was $0.03 \mathrm{ug} / 1$ (micrograms per litre). The compound 2,4,5-T is also a plant hormone that is almost insoluble in water. It has an estimated human toxicity of $0.6 \mathrm{~g} / \mathrm{kg}$ (grams per kilogram). A concentration of $0.01 \mathrm{ug} / 1$ was found in the watersediment mixture. A list and results of the compounds analyzed is given in table 3 .

\section{BACTERIOLOGY}

Observed fecal coliform densities for the Raystown Branch at Saxton (15620.) ranged from 3 to 5,400 colonies per $100 \mathrm{ml}$ (millilitres). The maximum densities were measured during high flow conditions. On six of nine sampling dates, the fecal coliform densities at Saxton were 100 colonies or less per 100 $\mathrm{ml}$, which included three samples when the streamflow was low and temperatures were high. Fecal coliform densities tended to decrease in a downstream direction at the other five main-stem sites. Fecal coliform densities measured at five of the six tributary sites showed no appreciable amount of fecal matter entering these streams. Fecal coliform densities at the Coffee Run site (1-5623.5) indicated a greater degree of fecal contamination there than at the other sites. The town of Entriken is less than $1 \mathrm{mi}(1.6 \mathrm{~km})$ upstream from the Coffee Run sampling site, and within a $1 \mathrm{mi}(1.6 \mathrm{~km})$ radius of this small town are from 15 to 20 farms, many of which raise various types of livestock. Septic tank effluents, along with livestock pollution, are probably the main contributing factors to the higher degree of fecal contamination at this site. 

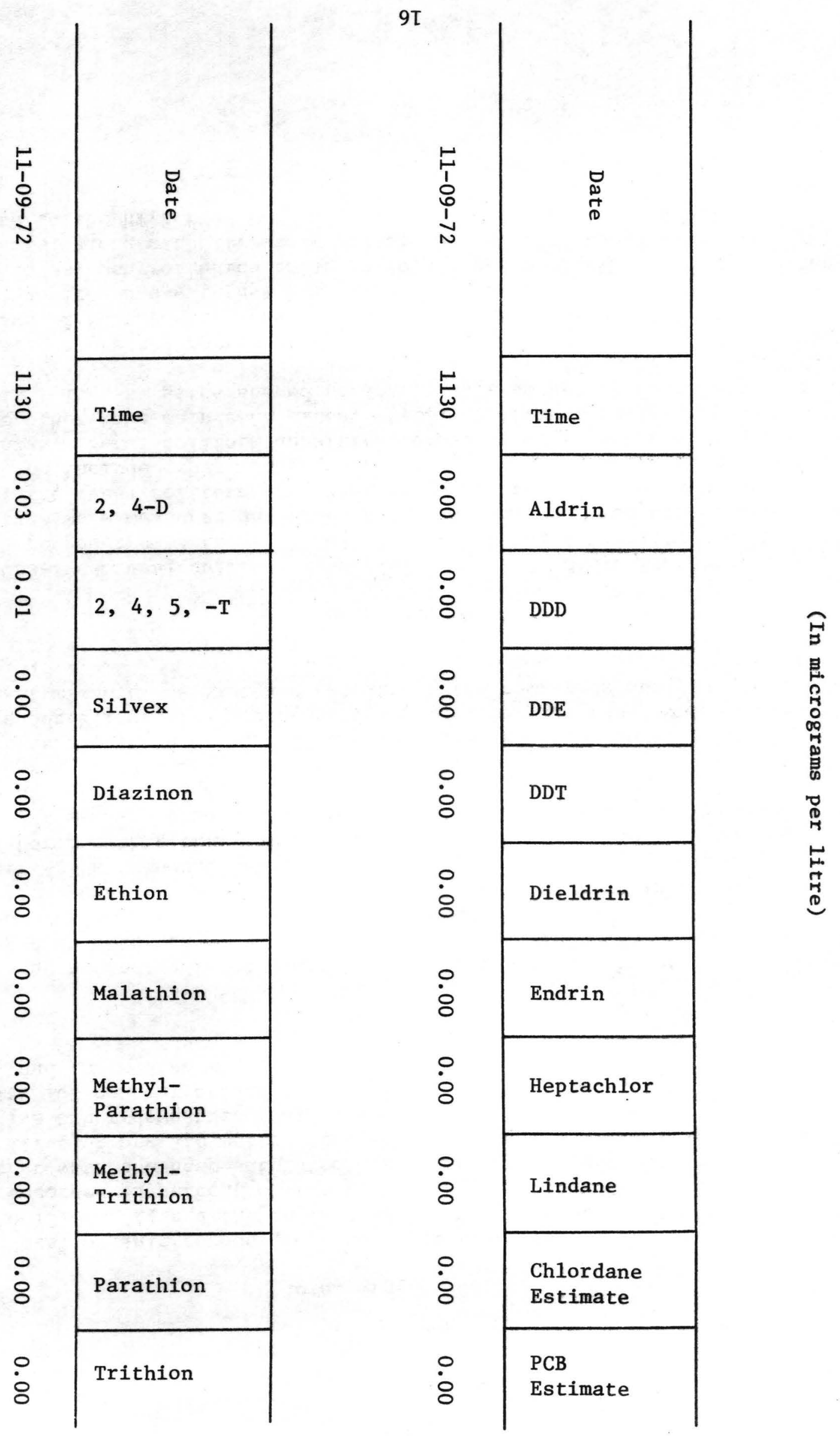
Fecal coliform densities measured at the Shoup Run site (1-5620.1) were very low, and on four occasions they were less than 1 colony per $100 \mathrm{ml}$. The low $\mathrm{pH}$ common to this stream is probably not conducive to growth of fecal coliform bacteria.

The highest fecal streptococcal densities were coincident with the highest fecal coliform densities. Only on a few occasions were extremely high fecal strep densities recorded, and these occurred when the streams were high and turbid.

The fecal coliform-fecal streptococcal ratio (FC/FS) is a very useful analytical tool provided that the samples taken are not more than 24 hours from the source of pollution and the range in $\mathrm{pH}$ of the source water falls within 4.0-9.0. A FC/FS ratio of 4 or greater indicates the water most likely contains wastes of human origin, and a ratio of 0.7 or less indicates wastes of animal, particularly livestock origin. A ratio between 0.7 and 4 represents an area of uncertain interpretation.

At the six main-stem sites, 66 percent of all samples collected had a FC/FS ratio of less than $0.7,7$ percent of the samples had a ratio greater than 4 , and 27 percent of the samples had a ratio between 0.7 and 4 . These data indicate the pollution to be predominantly of livestock origin. At the main-stem sites it is very difficult to determine if the sampling sites are within 24 hours flow of the pollution source; so, the reliability of these ratios are questionable.

At five of the six tributary sites 60 percent of all samples collected had a FC/FS ratio of less than $0.7,6$ percent of the samples had a ratio greater than 4, and 34 percent of the samples had a ratio between 0.7 and 4 . Ratios at the Shoup Run site were not used because of the low $\mathrm{pH}$ range common to this stream.

At the Coffee Run site, where a higher degree of fecal contamination was evident, an FC/FS ratio of less than 0.7 occurred 55 percent of the time, and a ratio greater than 4 occurred only 9 percent of the time, indicating the pollution to be predominantly of livestock origin.

The die-off rate for fecal coliform and fecal streptococcal bacterial is rather rapid. There is less than 20 percent survival for fecal coliform bacteria after 7 days in $10^{\circ}$ water (Millipore Corporation, 1974). The die-off rate increases more dramatically at higher temperatures. A very small percentage of the stream bacterial population will remain in the lake because of the short survival time of the fecal coliform bacteria and the relatively long retention time of the lake water.1/

1/ Theoretically, a complete exchange of water will take place in Raystown Lake every 229 days, based on an average annual inflow of $1,130 \mathrm{ft} 3 / \mathrm{s}$ $(32 \mathrm{~m} 3 / \mathrm{s})$. 


\section{SEDIMENTATION}

The average-annual suspended-sediment load for the Raystown Branch Juniata River at Saxton, Pa., (1-5620.) is 68,000 tons or $90 \mathrm{t} / \mathrm{mi}^{2}$ (35 t/ km2) (Williams and Reed, 1972). This is considered a relatively low yield for a drainage basin in the Valley and Ridge physiographic province.

Particle size analysis of a suspended-sediment sample collected at a mainstem site (1-5627.) during a high flow condition indicated that 4 percent of the suspended sediment is sand, 50 percent is silt, and 46 percent is clay. This corresponds to data collected by Williams and Reed (1972) indicating that the average composition of suspended sediment in the Susquehanna River basin is fairly consistent, being approximately 10 percent sand, 50 percent silt, and 40 percent clay.

Streambed samples were collected at three sites in the impoundment area (See fig. 2) and analyzed for particle size. In samples collected at two of the sites--Raystown Branch Juniata River near Marklesburg, Pa., (1-5624.) and Raystown Branch Juniata River near Hesston, $\mathrm{Pa}$. (1-5627.)--64 percent of the bed material was silt and clay and 36 percent of the bed material was sand and grave1. At the third site, which is $0.8 \mathrm{mi}(1.3 \mathrm{~km})$ upstream from station 1$5630 ., .94$ percent of the bed sample was silt and clay and 6 percent was sand and gravel. A complete breakdown of the particle size analyses at these three sites is in table 4 .

Studies by Brune (1953) indicate that the trap efficiency for Raystown Lake, using the capacity-inflow ratio, should be 95 percent or greater.

The drainage area of the Raystown Branch Juniata River at Saxton is 79 percent of the total drainage area controlled by the dam. The average-annual suspended-sediment yield at this site is 68,000 tons; so, the total amount of suspended sediment entering the lake will be approximately 86,000 tons. With a trap efficiency of 95 percent, the annual loss in storage capacity of the lake will be about 62 acre-feet $(0.076 \mathrm{hm} 3)$ or only 0.01 percent of the total capacity.

As mentioned earlier, the watershed is primarily wooded with only a small part in cultivation. No major sediment source areas such as strip mines or other disturbances exist in the drainage. With properly supervised development of the basin, no serious sediment problem is likely to occur in Raystown Lake.

\section{SOILS}

Soil samples were collected at four sites in the impoundment area. (See fig. 2.) Results of nitrogen and phosphorous analyses performed on the samples are in table 5. The soils were predominantly of the Barbour, Philo and Basher series (U.S. Department of Agriculture, 1972), which are highly fertile soils with silt-loam and sandy-loam textures. These soils are classified as deep and moderately well drained. 
Table 4.--Particle size analyses of bed material samples.

\begin{tabular}{l|c|c|c|c|c|}
\hline \multirow{2}{*}{ Location } & \multirow{3}{*}{ Date } & \multicolumn{4}{|c|}{ Percent } \\
\cline { 3 - 7 } & & $>2 \mathrm{~mm}$ & Sand & Silt & C1ay \\
\hline
\end{tabular}

Raystown Branch

Juniata River near

Marklesburg, PA (1-5624.)

\section{Raystown Branch}

Juniata River near

Hesston, PA (1-5627.)

Raystown Branch

Juniata River just above

old Raystown Dam, .8 mile

upstream from station

$1-5630$.
$9-13-72$

0

38

52

10

11

24

31

9-13-72

3

81 
Table 5.--Nitrogen and phosphorous analyses of soil samples.

(Results in milligrams per. kilogram)

\begin{tabular}{|c|c|c|c|c|c|c|c|}
\hline Soil Type & Site Location & $\begin{array}{l}\text { Latitude } \\
\text { Longitude }\end{array}$ & 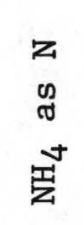 & $\begin{array}{l}z \\
\text { g } \\
\text { d } \\
\tilde{N} \\
\tilde{z}\end{array}$ & $\begin{array}{l}z \\
\text { m } \\
\text { m } \\
\text { g }\end{array}$ & 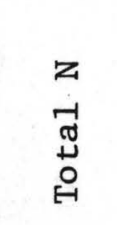 & 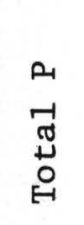 \\
\hline Barbour silt loam & $\begin{array}{l}\text { Near mainstem station } \\
\text { 1-5623. (Entriken } \\
\text { Bridge) }\end{array}$ & $\begin{array}{l}40^{\circ} 18^{\prime} 42^{\prime \prime} \mathrm{N} \\
78^{\circ} 10^{\prime} 47^{\prime \prime}\end{array}$ & 47 & 0.4 & 5.0 & 440 & 180 \\
\hline $\begin{array}{l}\text { Philo and Basher } \\
\text { silt loams, high } \\
\text { bottom }\end{array}$ & $\begin{array}{l}\text { Near mainstem station } \\
\text { 1-5624. (Trexler } \\
\text { Bridge) }\end{array}$ & $\begin{array}{l}40^{\circ} 21^{\prime} 12^{\prime \prime} \mathrm{N} \\
78^{\circ} 08^{\prime} 29^{\prime \prime}\end{array}$ & 43 & 0.2 & 4.7 & 247 & 190 \\
\hline $\begin{array}{l}\text { Philo and Basher } \\
\text { silt loams, high } \\
\text { bottom }\end{array}$ & $\begin{array}{l}\text { Near mainstem station } \\
1-5627 \text {. (Fink Bridge) }\end{array}$ & $\begin{array}{l}40^{\circ} 22^{\prime} 49^{\prime \prime} \mathrm{N} \\
78^{\circ} 03^{\prime} 48^{\prime \prime}\end{array}$ & 47 & 0.2 & 14 & 1460 & 220 \\
\hline $\begin{array}{l}\text { Barbour fine } \\
\text { sandy loam }\end{array}$ & $\begin{array}{l}\text { Near mainstem station } \\
1-5630 \text {. (Hawns Bridge) }\end{array}$ & $\begin{array}{l}40^{\circ} 25^{\prime} 30^{\prime \prime} . \mathrm{N} \\
78^{\circ} 01^{\prime} 42^{\prime \prime}\end{array}$ & 38 & 0.4 & 21 & 147 & 330 \\
\hline
\end{tabular}




\section{PROGNOSIS OF PHYSICAL, CHEMICAL,}

\section{AND BIOLOGICAL CHARACTERISTICS}

\section{OF RAYSTOWN LAKE}

Chemical and thermal stratification are expected to occur in Raystown Lake as in most reservoirs in the temperate zone. Throughout the summer, photosynthesis and oxygen from the atmosphere will produce oxygen saturation and supersaturated conditions in the epilimnion layer of the lake. The oxygen concentration in the epilimnion will probably have a diurnal cycle, with peak concentrations occurring in the evening on clear days and minimum concentrations occurring immediately after dawn. The hypolimnion layer of the lake will probably have lower concentrations of oxygen due to organic respiration and decomposition of decaying vegetation.

Nitrate-N and orthophosphate-P concentrations in the lake would have the same seasonal variations that were observed at the main inflow station at Saxton (fig. 4), with high concentrations occurring in the late winter and low concentrations occurring in the summer. Vertical distribution of nitrate-N in the lake waters would be related to lake productivity. The lowest concentrations of nitrate-N would occur in the upper epilimnion due to plankton utilization and would be highest in the lower hypolimnion due to biochemical reduction.

Orthophosphate-P concentrations in the lake would be somewhat lower than those observed at the main inflow station because of the greater biological demand in proportion to water volume. Concentrations in the upper waters will probably be low throughout the year, becoming depleted at times during the summer.

Raystown Lake will be similar to other main-stem reservoirs in that the littoral zone around much of the lake perimeter will be very narrow, and in places this zone may be completely absent. The lake will be situated between the Tarrace Mountain range to the east and the Allegrippis Ridge to the west. Very steep slopes are common where the lake waters will intercept these two mountains. The presence of a poor substrate, together with a sharp decrease in sunlight penetration would make it difficult for the establishment of rooted aquatic plants in this area. There will be inlets and coves however, where conditions would be favorable for the growth of aquatic plants. Data collected at all of the inflow sites indicate that nutrient levels of these streams are not extremely high; thus, excessive weed growth in the inlets and other shallow areas around the lake is not expected to occur. Aquatic weed surveys taken at five other impoundments (J. L. Barker, written commun., 1975) within a $50 \mathrm{mi}$ $(80 \mathrm{~km})$ radius of Raystown Lake give some indication of the principle plant species expected to be present in the lake. These species are: Potamogeton diversifolius (snailseed pondweed), Potamogeton crispus (curly-leaf pondweed), Potamogeton foliosus (leafy pondweed), Nuphar advena (spatterdock), Elodea canadensis (waterweed), and Najas minor. 
In general, phytoplankton communities in Raystown Lake would be composed mainly of blue-green algae, green algae, and diatoms. The diatoms would be the dominant type and have the greatest diversity of the phytoplankton community. Specific genera of three classes of algae expected to occur in the lake are as follows:

\begin{tabular}{c} 
Myxophyceae \\
(blue-green algae) \\
\hline \\
Anacystis \\
Anabaena \\
Aphanizomenon \\
Gomphosphaeria
\end{tabular}

\begin{tabular}{l}
$\begin{array}{l}\text { Chlorophyceae } \\
\text { (green algae) }\end{array}$ \\
\hline Desmidium \\
Pediastrum \\
Zygnema
\end{tabular}

\author{
Bacillariophyceae \\ (diatoms) \\ Asterionelza \\ Fragilaria \\ Navicula \\ Gomphonema \\ Cyclotelza \\ Tabezzaria
}

Zooplankton populations in the limnetic region of the lake would consist mainly of rotifers and microcrustaceans. Cladocerans and Copepods would constitute the majority of the zooplankton within the microcrustacean division. Densities of the zooplankton species would differ considerably throughout the lake, but species composition would most likely remain relatively constant in time (reid, 1961).

\section{SUMMARY}

The results of this preimpoundment study show that the Raystown Branch Juniata River and the main tributary streams flowing into the impoundment area are generally of very good quality and, therefore, conducive to forming a body of water that could support a balanced and diverse plant and animal population.

Bacterial densities at all sampling sites show no extensive amount of fecal contamination entering the impoundment area.

Unless large portions of this mostly quiescent watershed are disturbed, no serious sediment problems are likely to occur in the lake.

Total organic carbon concentrations, and the dissolved-oxygen content of all the sampled waters, show no excessive amounts of organic matter that could lead to overall oxygen depletion and a general degradation of the water quality.

Observed nutrient levels of inflowing streams together with the morphological features of the lake basin indicate the unlikelihood of cultural eutrophication occurring in the lake.

Aquatic weed and algal growth will occur in parts of the lake, but are not expected to present management problems. 


\section{SELECTED REFERENCES}

Brune, G. M., 1953, Trap efficiency of reservoirs: Am. Geophy. Union Trans., v. 34, No. 3, p. 407-418.

Millipore Corporation, 1974, Field procedures in water microbiology: $\mathrm{AB} 314$, p. 3 .

Reid, G. K., 1961, Ecology of inland waters and estuaries: New York, Reinhold Publishing Co., 294 p.

U.S. Department of Agriculture, 1972, Soil survey interpretations for Huntingdon County, Pennsylvania: U.S. Soil Conservation Service, v. $1,144 \mathrm{p}$.

Williams, K. F., and Reed, L. A., 1972, Appraisal of stream sedimentation in the Susquehanna River basin: U.S. Geol. Survey Water-supply Paper 1532-F, 24 p. 
